\title{
Water Erosion Prediction Project (WEPP): Development History, Model Capabilities, AND FUTURE ENHANCEMENTS
}

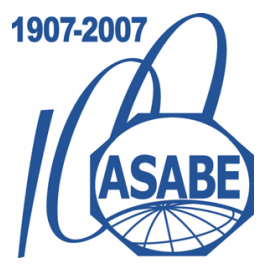

\author{
D. C. Flanagan, J. E. Gilley, T. G. Franti
}

\begin{abstract}
The Water Erosion Prediction Project (WEPP) was initiated in August 1985 to develop new-generation water erosion prediction technology for use by federal action agencies involved in soil and water conservation and environmental planning and assessment. Developed by the USDA-ARS as a replacement for empirically based erosion prediction technologies, the WEPP model simulates many of the physical processes important in soil erosion, including infiltration, runoff, raindrop and flow detachment, sediment transport, deposition, plant growth, and residue decomposition. The WEPP project included an extensive field experimental program conducted on cropland, rangeland, and disturbed forest sites to obtain data required to parameterize and test the model. A large team effort at numerous research locations, ARS laboratories, and cooperating land-grant universities was needed to develop this state-of-the-art simulation model. WEPP project participants met frequently to coordinate their efforts. The WEPP model can be used for common hillslope applications or on small watersheds. Because it is physically based, the model has been successfully used in the evaluation of important natural resources issues throughout the U.S. and in many other countries. Upgrades to the modeling system since the 1995 DOS-based release include Microsoft Windows operating system graphical interfaces, web-based interfaces, and integration with Geographic Information Systems. Improvements have been made to the watershed channel and impoundment components, the CLIGEN weather generator, the daily water balance and evapotranspiration routines, and the prediction of subsurface lateral flow along low-permeability soil layers. A combined wind and water erosion prediction system with easily accessible databases and a common interface is planned for the future.
\end{abstract}

Keywords. Computer simulation, Deposition, Erosion mechanics, Erosion models, Hydrology, Runoff, Sediment, Sediment transport, Soil conservation, Soil erosion.

$\mathrm{U}$ SDA Agricultural Research Service (ARS) personnel and their cooperators initiated the Water Erosion Prediction Project (WEPP) in August 1985 to produce new-generation water erosion prediction technology for use by federal action agencies involved in soil and water conservation and environmental planning and assessment. At that time, the soil erosion prediction tool in widespread use was the Universal Soil Loss Equation (USLE; Wischmeier and Smith, 1978); Gilley and Flanagan (2007) describe the events leading to the release of the USLE. While the USLE was used extensively to predict long-term average annual soil loss, it was a mature technology that could not easily be expanded to meet the ever

Submitted for review in March 2007 as manuscript number SW 6942; approved for publication by the Soil \& Water Division of ASABE in July 2007 as a contribution to the ASABE 100th Anniversary Soil and Water Invited Review Series.

The authors are Dennis C. Flanagan, ASABE Member Engineer, Agricultural Engineer, USDA-ARS National Soil Erosion Research Laboratory, West Lafayette, Indiana; John E. Gilley, ASABE Member Engineer, Agricultural Engineer, USDA-ARS, University of Nebraska, Lincoln, Nebraska; and Thomas G. Franti, ASABE Member Engineer, Associate Professor, Department of Biological Systems Engineering, University of Nebraska, Lincoln, Nebraska. Corresponding author: Dennis C. Flanagan, USDA-ARS NSERL, 275 S. Russell St., West Lafayette, IN 47907-2077; phone: 765-494-7748; fax: 765-494-5948; e-mail: flanagan@purdue.edu. increasing needs of conservationists and environmental managers. For example, USLE was only applicable to detaching regions of a hillslope, and could not estimate sediment deposition or sediment delivery from fields to off-site channels or streams. In addition, USLE had no capabilities to estimate runoff, spatial locations of soil loss on a hillslope profile or within a small watershed, channel erosion, effects of impoundments, recurrence probabilities of erosion events, or watershed sediment yield. The WEPP model was developed to address all of these needs, and to serve as a replacement for empirically based erosion prediction technologies like USLE.

Development of the WEPP model involved research engineers and scientists creating model logic and code, conducting field and laboratory experiments, working on parameterization and model testing, and creating user interfaces and databases. During the first ten years of development, leading up to the 1995 model release, over 35 meetings were held across the U.S. to coordinate project activities. Field rainfall simulation experiments were conducted on over 50 experimental sites, ranging from western rangelands to eastern croplands. Four senior scientists have served as project leaders over the past 22 years of WEPP development. The history of how this program was managed, the soil erosion prediction technology developed, and the future of WEPP technology are described in this article. 
Table 1. Important dates and milestones for the WEPP project.

\begin{tabular}{|c|c|}
\hline April 1985 & ARS scientists from across the U.S. meet at Ramada Inn in Lafayette, Indiana, for "A Workshop on Replacement of the USLE". \\
\hline August 1985 & Initial core team meeting convened by George R. Foster, Hydraulic Engineer and WEPP Project Leader, in West Lafayette, Indiana. \\
\hline January 1987 & User requirements published (Foster and Lane, 1987). \\
\hline March 1987 & Project described to top agency representatives in Washington, D.C. \\
\hline August 1987 & Leonard J. Lane, Hydrologist, Tucson, Arizona, appointed WEPP Project Leader. \\
\hline 1987-1988 & Cropland field experiments conducted on 33 soils across the U.S. \\
\hline 1987-1988 & Rangeland field experiments conducted at 24 sites in the western U.S. \\
\hline August 1989 & Prototype hillslope model v89 delivered to user agencies at meeting held at Ramada Inn in Lafayette, Indiana. \\
\hline August 1989 & John M. Laflen, Agricultural Engineer and NSERL Director, West Lafayette, Indiana, appointed WEPP Project Leader. \\
\hline August 1989 & Hillslope model documentation published (Lane and Nearing, 1989). \\
\hline August 1989 & Compendium of cropland soil erodibility data published (Elliot et al., 1989). \\
\hline June 1990 & WEPP project participants receive USDA Superior Service Group Award. \\
\hline May 1993 & WEPP technical review held at University Inn in West Lafayette, Indiana. \\
\hline August 1995 & Hillslope and watershed model (v95.7) delivered to user agencies at special SWCS Symposium in Des Moines, Iowa. \\
\hline August 1995 & Hillslope and watershed model documentation published (Flanagan and Nearing, 1995). \\
\hline August 1995 & User summary published (Flanagan and Livingston, 1995). \\
\hline April 1999 & Dennis C. Flanagan, Agricultural Engineer, West Lafayette, Indiana, appointed WEPP Project Leader. \\
\hline May 1999 & Graphical Windows interface released with WEPP model version 99.5. \\
\hline January 2000 & Web-based interfaces for forest roads and hillslopes released by Forest Service. \\
\hline March 2001 & Updated WEPP model (v2001.3) released with watershed channel and impoundment improvements. \\
\hline April 2001 & GeoWEPP ArcView extension software for use with the model released. \\
\hline Sept. 2004 & Web-based interface for cropland and rangeland applications released with WEPP model version 2004.7. \\
\hline May 2006 & Updated WEPP model v2006.5 and interfaces released with enhancements for forest hydrology. \\
\hline
\end{tabular}

\section{Project Management History}

Federal action agencies that manage soil and water resources must assess the soil erosion impact of diverse land uses ranging from cotton fields to mountain forests. To ensure that the needs of the user agencies were adequately addressed, agency representatives were active participants in the WEPP project from its inception. Representatives of action agencies helped define user needs and provided essential background on the range of resource issues that WEPP would need to address. The time required for the model to run and its ease of use were issues critical to the user agencies. A timeline identifying important dates and milestones for the WEPP project is shown in table 1.

A core team made up of project leaders and technical experts from across the U.S. supervised WEPP project management and development. The core team met regularly to review progress and discuss model development and planning (table 2). Timely completion of the WEPP project required that important issues be resolved at core team meetings. Thus, development of the meeting agenda was an important responsibility shared jointly by the project leader and local meeting host. Goals of the core team meetings included updating WEPP participants on the status of issues and action items identified in previous meetings, and discussing technical items requiring attention. All individuals in attendance, including guests, were encouraged to fully participate in the discussions and provide appropriate input.

Field tours sometimes occurred during core team meetings with the goal of familiarizing WEPP participants with local conditions across the country, and helping to identify the range of issues that should be addressed by the model. The research program of the meeting host was usually highlighted, and managers at the host location were invited to address the group. Core team meeting participants soon became well acquainted with the research programs of individuals working in diverse natural resource areas throughout the U.S.
Table 2. WEPP Core Team and subgroup meetings, 1985-1995.

\begin{tabular}{|c|c|c|}
\hline Dates & Location & Attendees \\
\hline August $20-22,1985$ & West Lafayette, Indiana & 12 \\
\hline November 18-22, 1985 & West Lafayette, Indiana & 15 \\
\hline February 25-27, 1986 & Tucson, Arizona & 23 \\
\hline July 22-25, 1986 & Ames, Iowa & 31 \\
\hline August 19-22, 1986[a] & West Lafayette, Indiana & \\
\hline November 3-7, 1986[a] & Tucson, Arizona & \\
\hline November 18-20, 1986 & Oxford, Mississippi & 30 \\
\hline January 26-29, 1987[a] & West Lafayette, Indiana & \\
\hline March 16-19, 1987 & Silver Spring, Maryland & 35 \\
\hline June 8-11, 1987[a] & West Lafayette, Indiana & \\
\hline August 25-27, 1987 & Boise, Idaho & 49 \\
\hline January 18-22, 1988[a] & Tucson, Arizona & \\
\hline February 22-25, 1988 & Kingston, Oklahoma & 46 \\
\hline April 11-15, 1988[a] & Tucson, Arizona & \\
\hline September 26-29, 1988 & Columbia, Missouri & 65 \\
\hline January 30 - February 2, 1989 & Tucson, Arizona & 71 \\
\hline April 18-20, 1989 & Lincoln, Nebraska & 52 \\
\hline August 29-31, 1989 & Lafayette, Indiana & 90 \\
\hline November $13-15,1989^{[a]}$ & Tucson, Arizona & 27 \\
\hline January 29-31, 1990[a] & West Lafayette, Indiana & 27 \\
\hline March 5-8, 1990 & Fort Worth, Texas & 37 \\
\hline June $18-19,1990^{[a]}$ & West Lafayette, Indiana & \\
\hline September 24-27, 1990 & Lakewood, Colorado & 50 \\
\hline February $11-13,1991[\mathrm{a}]$ & Tucson, Arizona & \\
\hline April 2-4, 1991 & Moscow, Idaho & 32 \\
\hline October 22-24, 1991 & Greenville, South Carolina & 50 \\
\hline March 23-26, 1992[a] & West Lafayette, Indiana & 35 \\
\hline June 2-4, 1992 & Oxford, Mississippi & \\
\hline September 8-11, 1992[a] & West Lafayette, Indiana & \\
\hline November 5-6, 1992 & Bloomington, Minnesota & 30 \\
\hline April 14-15, 1993[a] & Beltsville, Maryland & 16 \\
\hline May 4-7, 1993[a] & West Lafayette, Indiana & 29 \\
\hline June 23-25, 1993 & Spokane, Washington & 39 \\
\hline July $13-15,1993^{[a]}$ & Morris, Minnesota & \\
\hline January 25-26, 1994[a] & West Lafayette, Indiana & \\
\hline March 15-17, 1994 & West Lafayette, Indiana & \\
\hline August 9-11, 1995 & Des Moines, Iowa & \\
\hline
\end{tabular}


Table 3. Selected model components, team members and their work locations, and dates of development.

\begin{tabular}{|c|c|c|c|}
\hline $\begin{array}{l}\text { Model } \\
\text { Component }\end{array}$ & Member(s) & Location(s) & Dates \\
\hline \multirow{7}{*}{$\begin{array}{l}\text { Hillslope } \\
\text { erosion } \\
\text { component }\end{array}$} & G. R. Foster & West Lafayette, Indiana & $1985-1987$ \\
\hline & J. C. Ascough II & $" \%$ & $1985-1988$ \\
\hline & M. A. Nearing & $"$, & 1987-1995 \\
\hline & L. M. Risse &,$"$ & 1992-1995 \\
\hline & L. J. Lane & Tucson, Arizona & 1985-1995 \\
\hline & S. C. Finkner & Lincoln, Nebraska & 1986-1989 \\
\hline & D. C. Flanagan & West Lafayette, Indiana & 1987-2007 \\
\hline \multirow{6}{*}{$\begin{array}{l}\text { Hydrology, } \\
\text { continuous } \\
\text { simulation }\end{array}$} & L. J. Lane & Tucson, Arizona & 1985-1995 \\
\hline & J. J. Stone & $" »$ & $" »$ \\
\hline & M. Hernandez & $"$, & $"$, \\
\hline & V. L. Lopes & , , & $"$, \\
\hline & W. J. Rawls & Beltsville, Maryland & 1985-1995 \\
\hline & M. A. Nearing & West Lafayette, Indiana & $1987-1995$ \\
\hline \multirow{5}{*}{$\begin{array}{l}\text { Climate } \\
\text { generation }\end{array}$} & A. D. Nicks & Durant, Oklahoma & 1985-1997 \\
\hline & L. J. Lane & Tucson, Arizona & 1985-1989 \\
\hline & E. Gander & Durant, Oklahoma & 1986-1995 \\
\hline & C. R. Meyer & West Lafayette, Indiana & $1997-2007$ \\
\hline & D. E. Hall & Moscow, Idaho & 1997-2001 \\
\hline \multirow{5}{*}{$\begin{array}{l}\text { Flow } \\
\text { hydraulics }\end{array}$} & J. E. Gilley & Lincoln, Nebraska & 1985-1995 \\
\hline & S. C. Finkner & & 1985-1989 \\
\hline & E. R. Kottwitz & ", & $川$ \\
\hline & M. R. Weltz & Tucson, Arizona & 1985-1995 \\
\hline & L. J. Lane & ", & $"$, \\
\hline \multirow{4}{*}{$\begin{array}{l}\text { Water balance, } \\
\text { percolation, } \\
\text { drainage }\end{array}$} & M. R. Savabi & West Lafayette, Indiana & 1987-1999 \\
\hline & R. W. Skaggs & Raleigh, North Carolina & 1989-1995 \\
\hline & J. R. Williams & Temple, Texas & 1987-1995 \\
\hline & W. R. Rawls & Beltsville, Maryland & 1985-1995 \\
\hline \multirow{4}{*}{$\begin{array}{l}\text { Plant } \\
\text { growth }\end{array}$} & E. E. Alberts & Columbia, Missouri & $1985-1995$ \\
\hline & F. Ghidey & $" »$ & $"$, \\
\hline & J. G. Arnold & West Lafayette, Indiana & 1991-1995 \\
\hline & M. A. Weltz & Tucson, Arizona & 1985-1995 \\
\hline
\end{tabular}

(continued)

Often, there was not sufficient time available during a core team meeting to discuss important technical issues. Therefore, subgroup meetings were sometimes convened (e.g., field erodibility studies, frozen soils, irrigation modeling, etc.). Because the subgroups were much smaller, critical issues could be more easily resolved. The subgroup meetings were usually conducted in the same manner as the core team meetings, and a detailed agenda was prepared.

An initial model delivery date of 1989 was established. After each of the core team meetings and several of the subgroup meetings conducted between August 1985 and June 1992, J. E. Gilley assembled and distributed a meeting report and a list of action items to the entire WEPP team. Each action item identified a specific assignment, individuals responsible for completing the task, and the anticipated completion date. Critical path analysis was used as necessary to determine completion dates. It was recognized that completing critical assignments on time was essential to keep the entire group on schedule.

A USDA-ARS National Program Leader (NPL) was responsible for coordinating erosion research within ARS, and the NPL usually attended core team meetings. The NPL provided administrative support for the project and kept top agency administrators informed of project activities and requirements. ARS National Program Leaders directing erosion research since the inception of WEPP include: C. R.
Table 3 (cont'd). Selected model components, team members and their work locations, and dates of development.

\begin{tabular}{|c|c|c|c|}
\hline $\begin{array}{l}\text { Model } \\
\text { Component }\end{array}$ & Member(s) & Location(s) & Dates \\
\hline \multirow{7}{*}{$\begin{array}{l}\text { Soil } \\
\text { component }\end{array}$} & E. E. Alberts & Columbia, Missouri & 1985-1995 \\
\hline & J. M. Laflen & West Lafayette, Indiana & $1985-1999$ \\
\hline & M. A. Nearing & $"$ & 1987-1995 \\
\hline & L. M. Risse & 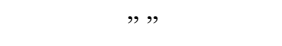 & 1992-1995 \\
\hline & J. R. Simanton & Tucson, Arizona & 1985-1995 \\
\hline & M. A. Weltz & $"$, & " \\
\hline & F. B. Pierson & Boise, Idaho & $1985-1995$ \\
\hline \multirow{4}{*}{$\begin{array}{l}\text { Residue } \\
\text { decomposition } \\
\text { and management }\end{array}$} & D. E. Stott & West Lafayette, Indiana & $1986-1995$ \\
\hline & E. E. Alberts & Columbia, Missouri & 1985-1989 \\
\hline & F. Ghidey & & \\
\hline & M. A. Weltz & Tucson, Arizona & $1985-1995$ \\
\hline \multirow{9}{*}{$\begin{array}{l}\text { Winter } \\
\text { processes }\end{array}$} & R. A. Young & Morris, Minnesota & 1985-1995 \\
\hline & G. Benoit & & "» \\
\hline & J. Witte & $" »$ & $"$ \\
\hline & M. R. Savabi & West Lafayette, Indiana & $1990-1995$ \\
\hline & D. K. McCool & Pullman, Washington & $1985-2007$ \\
\hline & J. Q. Wu & & 2001-2007 \\
\hline & S. Dun & $" »$ & "» \\
\hline & P. Singh & " , & $"$, \\
\hline & C. Greer & $" ”$ & $" »$ \\
\hline \multirow[t]{4}{*}{ Irrigation } & J. E. Gilley & Lincoln, Nebraska & $1985-1995$ \\
\hline & E. R. Kottwitz & & \\
\hline & D. L. Bjorneberg & Kimberly, Idaho & 1996-2007 \\
\hline & D. C. Kincaid & & 1996-2004 \\
\hline \multirow{5}{*}{$\begin{array}{l}\text { Channel and } \\
\text { watershed } \\
\text { components }\end{array}$} & J. C. Ascough II & West Lafayette, Indiana & $1992-1997$ \\
\hline & C. Baffaut & & \\
\hline & M. A. Nearing & $"$ & $" »$ \\
\hline & D. C. Flanagan & $"$ & $"$, \\
\hline & B. Y. Liu & $" »$ & "” \\
\hline \multirow{7}{*}{$\begin{array}{l}\text { Impoundment } \\
\text { component }\end{array}$} & B. J. Barfield & Stillwater, Oklahoma & 1991-1995 \\
\hline & M. R. Lindley & Lexington, Kentucky & $"$ \\
\hline & J. C. Ascough II & West Lafayette, Indiana & $" ”$ \\
\hline & B. N. Wilson & St. Paul, Minnesota & $"$, \\
\hline & J. Q. Wu & Pullman, Washington & 1999-2002 \\
\hline & S. Dun & & \\
\hline & W. J. Elliot & Moscow, Idaho & $"$, \\
\hline \multirow{4}{*}{$\begin{array}{l}\text { Water balance } \\
\text { and subsurface } \\
\text { lateral flow }\end{array}$} & J. Q. Wu & Pullman, Washington & $2000-2006$ \\
\hline & S. Dun & $" »$ & $" »$ \\
\hline & A. C. $\mathrm{Xu}$ & 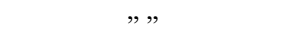 & 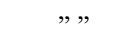 \\
\hline & W. J. Elliot & Moscow, Idaho & $" ”$ \\
\hline
\end{tabular}

Amerman (August 1985 to July 1987), W. D. Kemper (August 1987 to August 1990), S. Rawlins (September 1990 to October 1992), C. R. Amerman (November 1992 to December 2002), and M. A. Weltz (January 2003 to present).

Beginning in August 1987, development of the Wind Erosion Prediction System (WEPS), an improved wind erosion prediction technology, closely paralleled WEPP model development (Hagen et al., 1996). Members of the Wind Erosion Research Unit (WERU) at Manhattan, Kansas, provided project leadership for WEPS. Representatives of the WEPS project often attended WEPP core team meetings and have collaborated with WEPP project members for many years on several joint activities.

The WEPP project was initiated to provide a specific product within an established timeline. Many individuals participated in project activities, made important contributions, and then redirected their efforts to other pursuits. As the project progressed and new issues evolved, 

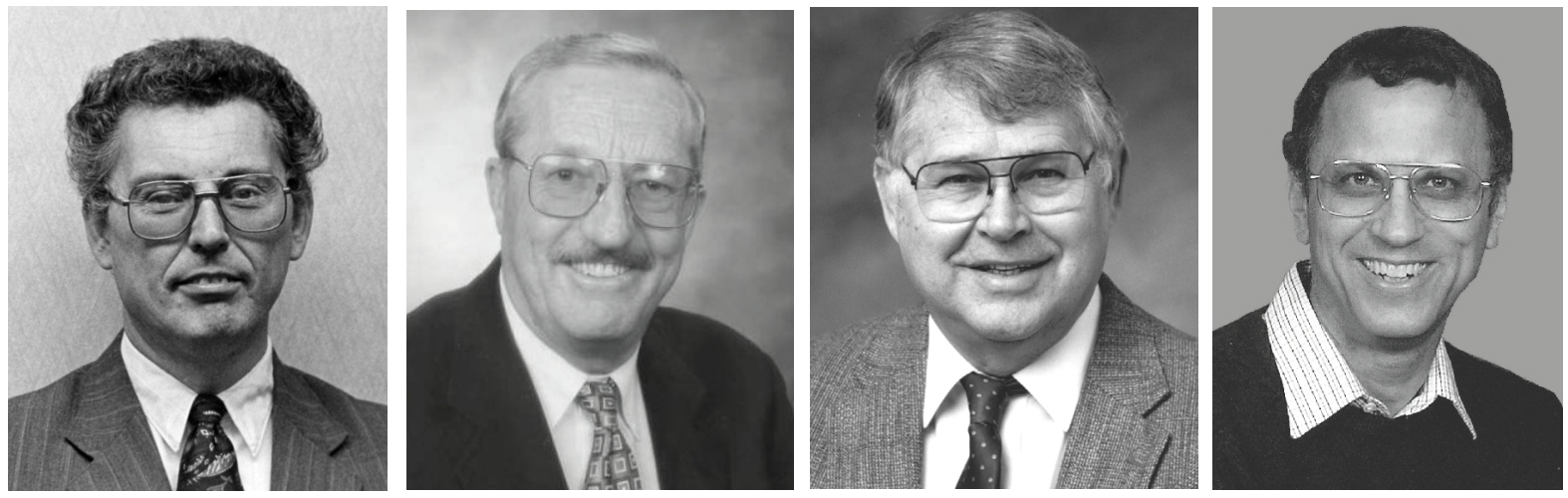

Figure 1. WEPP Project Leaders (left to right): George R. Foster (1985-1987), Leonard J. Lane (1987-1989), John M. Laflen (1989-1999), and Dennis C. Flanagan (1999-present).

participation by additional individuals was required to provide renewed energy and expertise. Flanagan et al. (2001) provide additional information concerning WEPP model development.

An extensive team effort at numerous research locations, ARS laboratories, and cooperating land-grant universities was needed to develop this state-of-the-art simulation model. Over 200 individuals representing different federal agencies, universities, disciplines, and international locations have made significant contributions to the WEPP project. Managing and coordinating the efforts of this diverse group was a substantial administrative challenge. The four ARS senior scientists who served as Project Leaders are identified in table 1 and figure 1. Many of the WEPP participants and the areas in which they contributed are shown in table 3.

\section{WEPP ACTIVITIES: 1985 to 1989}

G. R. Foster (fig. 1), hydraulic engineer, National Soil Erosion Research Laboratory (NSERL), West Lafayette, Indiana, convened the first WEPP core team meeting on August 20-22, 1985, at the NSERL (table 1). At this meeting, one of the key items requiring attention was development of a user requirements document. Members of the core team visited each of the four Soil Conservation Service (SCS) Technical Centers (Chester, Pennsylvania; Lincoln, Nebraska; Portland, Oregon; and Fort Worth, Texas) to receive input on user needs. Selected individuals from each of the cooperating action agencies, including the Bureau of Land Management (BLM), Forest Service (FS), and SCS, also provided suggestions. The final WEPP user requirements (Foster and Lane, 1987) served as a valuable guide in directing project activities.

Information contained in the user requirements was presented to top agency representatives of ARS, BLM, FS, and SCS in March 1987. Agency administrators then signed the user requirements document, indicating that they concurred with its contents and supported development of the WEPP model. Once agency managers assigned personnel and resources to the WEPP project, it was anticipated that they would be willing to adopt and implement the final computer technology being developed specifically for their use. L. J. Lane (fig. 1), hydrologist, Tucson, Arizona, became WEPP Project Leader in August 1987 upon the departure of G. R. Foster from ARS.

Several field and laboratory experimental studies were conducted as part of the WEPP project. Of particular importance were rainfall simulation tests conducted on 33 cropland soils (Gilley et al., 1990; Laflen et al., 1991) and 18 rangeland sites (Simanton et al., 1991) to collect rainfall, runoff, soil loss, and soil property data (fig 2). This information was used in the development of predictive equations, and for model parameterization and testing.

The field rainfall simulation activities often received considerable attention from local officials and media. Public and private cooperators were pleased to participate in a well-recognized national program and to have their local conditions adequately represented in the WEPP database. Newspaper, magazine, and television reporters often interviewed WEPP representatives at many of the field experimental sites.

The basic WEPP hillslope model components were identified early in the project by the core team, and included weather generation, surface hydrology, hydraulics of overland flow, hillslope erosion, water balance, plant growth, residue management and decomposition, soil disturbance by tillage, and irrigation (Foster and Lane, 1987). A unique aspect of the WEPP technology was to be the separation of the erosion processes into rill detachment (as a function of excess flow shear stress) and interrill detachment (as a function of rainfall intensity) (Nearing et al., 1989). Additionally, the model would simulate sediment transport and deposition, and off-site sediment particle-size distribution. These items were desired by the model users to allow better assessment of soil erosion at a site, and subsequent sediment transport to channels and impoundments in small field/farm watersheds (Foster and Lane, 1987).

Extensive programming of the initial WEPP Fortran science model computer code was done at both the NSERL in West Lafayette, Indiana (1985-1987) and at the ARS Southwest Watershed Research Center in Tucson, Arizona (1987-1989). WEPP staff instrumental in creating the first WEPP computer program version (v89) included: J. C. Ascough II, J. E. Ferris, S. C. Finkner, D. C. Flanagan, G. R. Foster, F. Ghidey, M. Hernandez, L. J Lane, V. L. Lopes, M. A. Nearing, A. D. Nicks, E. Perry, M. R. Savabi, J. J. Stone, and M. A. Weltz. The prototype Hillslope Profile Model and Documentation (v89) (Lane and Nearing, 1989) was delivered to user agency representatives at a meeting held in Lafayette, Indiana, on August 29-31, 1989. A compendium of cropland soil erodibility data was also published in 1989 (Elliot et al., 1989). J. M. Laflen (fig. 1), Director, NSERL, 


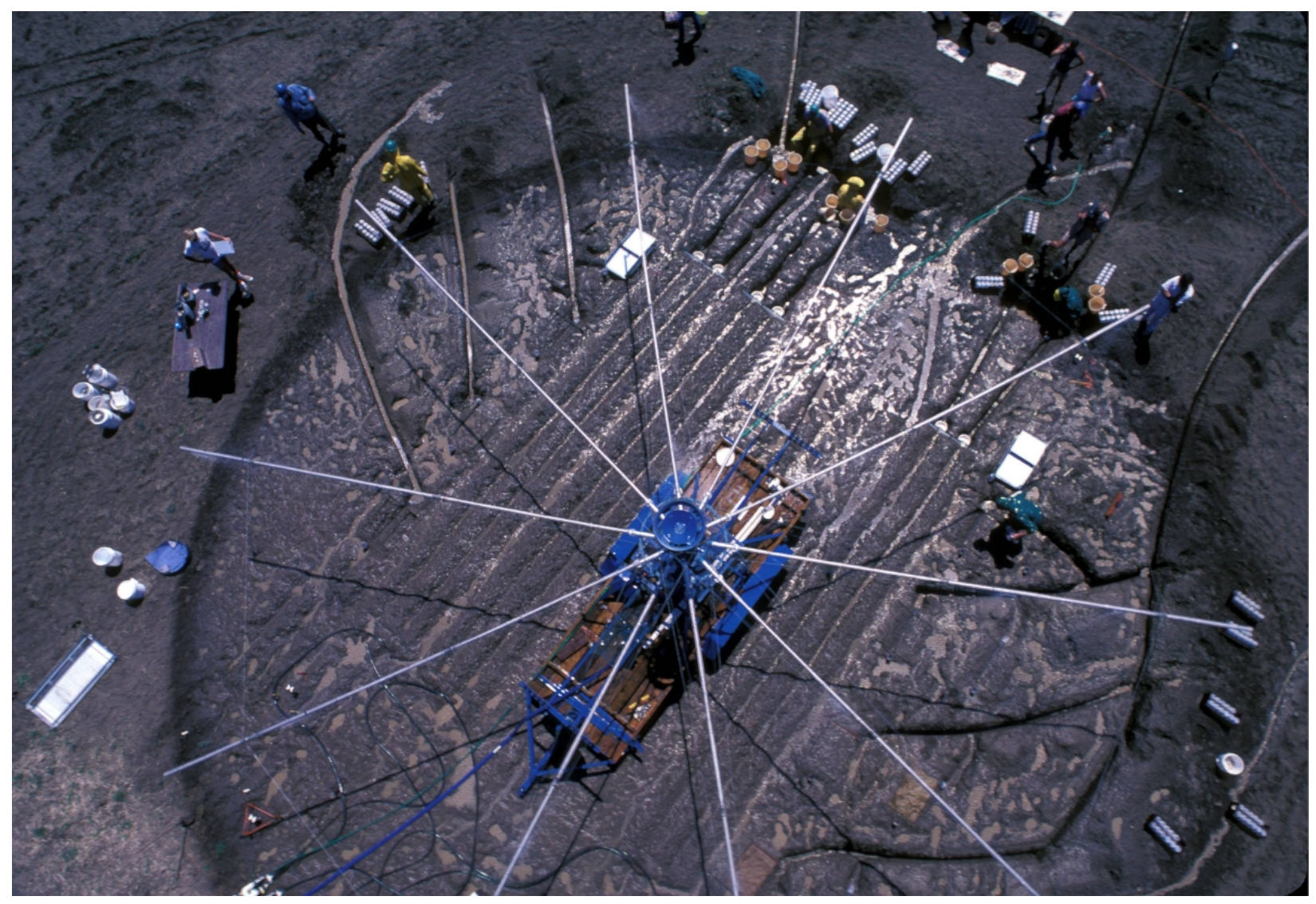

Figure 2. Rainfall simulation experiments were conducted on 33 benchmark cropland soils during 1987-1988 (shown here is the Cottonwood, South Dakota site). ARS photo by Tim McCabe.

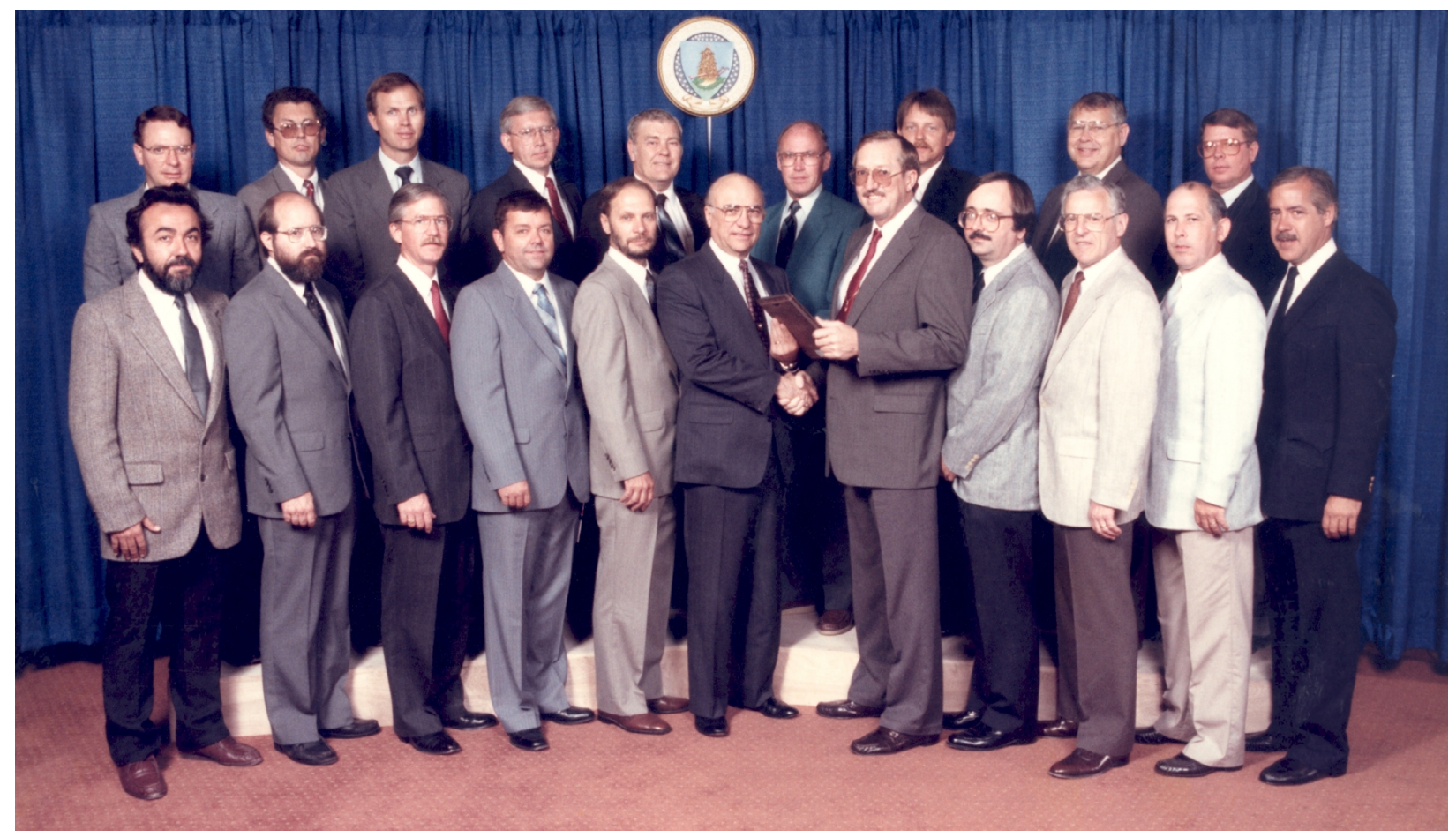

Figure 3. WEPP project participants with Secretary of Agriculture Clayton K. Yeutter on June 13, 1990, receiving the USDA Superior Service Group Award. Top row: J. E. Gilley, G. R. Foster, J. Nordin, G. A. Weesies, A. D. Nicks, R. A. Young, M. A. Weltz, J. M. Laflen, and D. Fox. Bottom row: V. L. Lopes, M. A. Nearing, D. L. Schertz, J. R. Simanton, W. Osterkamp, C. K. Yeutter, L. J. Lane, E. E. Alberts, N. Miller, W. J. Rawls, and G. Wingate. 
West Lafayette, Indiana, was appointed Project Leader in August 1989. For model development efforts conducted through 1989, WEPP project participants received a USDA Superior Service Group Award in June 1990 during a USDA Award Ceremony in Washington, D.C. (fig. 3).

\section{WEPP ACTIVITIEs: 1989 to 1995}

Beginning in late 1989, further WEPP model development became largely the responsibility of personnel at the USDA-ARS NSERL in West Lafayette, Indiana. As WEPP Project Leader, J. M. Laflen supervised project activities, coordinated the efforts of team members across the U.S., and was responsible for soil erodibility parameterization. M. A. Nearing served as WEPP Technical Director from 1992 to 1995 and led model testing, hydrologic parameterization, and model validation efforts. D. C. Flanagan was responsible for further development of the WEPP Hillslope Profile Model, interfaces, and documentation. Development of the WEPP Watershed Model was the responsibility of J. C. Ascough II. During 1989-1995, many components were added to the model code that had been intended but were not included in the 1989 release. New and/or improved components incorporated into WEPP included non-uniform hydrology, irrigation, winter processes, subsurface drainage, plant growth, residue decomposition, channel hydrology, channel erosion, and impoundment sedimentation. Other NSERL employees who assisted with WEPP activities included: J. G. Arnold, C. Baffaut, L. A. Deer, C. C. Drungil, J. E. Ferris, K. A. Franzmeier, A. J. Ketchum, S. J. Livingston, B. Liu, C. R. Meyer, L. M. Risse, D. E. Stott, G. A. Weesies, D. A. Whittemore, and X. J. Zhang.

A documented and validated WEPP model (v95.7) was presented to user agency representatives at a special symposium sponsored by the Soil and Water Conservation Society on August 9-11, 1995, in Des Moines, Iowa. The symposium included technical sessions describing the scientific components of WEPP and WEPS, and a model demonstration and training workshop. During a formal presentation ceremony, copies of the model software were provided on a multi-media CD-ROM to federal agency representatives (Flanagan, 1995; Flanagan et al., 1995). Paper documentation (Flanagan and Nearing, 1995; Flanagan and Livingston, 1995) was also distributed to ARS, BLM, FS, and SCS employees and all symposium participants.

The 1995 model release included a DOS-based interface, originally created to expedite model testing and validation by individuals developing WEPP (Flanagan et al., 1994). From 1988 to 1992, SCS employees worked on development of their own OCP (operational computer program) interface but abandoned that effort in 1993. The WEPP DOS interface allowed simulation of both hillslope profiles and watersheds. However, it was almost entirely text-based and difficult for some users to understand and apply.

Substantial changes in both federal soil conservation programs and computer operating systems occurred from 1994 to 1996. SCS was reorganized into the Natural Resources Conservation Service (NRCS) on October 14, 1994, shifting its focus from preservation of soil resources to protection of air, soil, water, and wildlife habitat. The SCS Technical Centers were closed as part of the reorganization, disrupting many of the close working relationships established among ARS and SCS employees. During this period, personal computer operating systems were shifting from a text-based MS-DOS format to a graphically based Microsoft Windows structure. In addition, PC microprocessors were doubling in speed about every six months.

\section{WEPP ACtivities: 1995 to Present}

After delivery of the WEPP model in 1995, the USDA-ARS NSERL assumed responsibility for WEPP model testing, implementation, and maintenance. J. M. Laflen continued as WEPP Project Leader and worked on model testing and technology transfer activities. Many of the other WEPP project participants soon shifted their attention to other activities after 1995. M. A. Nearing and D. C. Flanagan redirected their focus from WEPP model development to laboratory and field soil erosion research, as well as modeling applications.

Following model delivery in 1995, the WEPP computer program was to be tested, revised, and implemented by representatives of the user agencies. A team of NRCS employees conducted WEPP model tests in late 1995 and early 1996. After these tests, it was recommended that graphical Windows-based interfaces be developed for WEPP. Model tests at selected FS sites also indicated that improved interfaces would be needed before their staff could fully implement the WEPP model.

In response to suggestions made by the user agencies, ARS began efforts in 1996 to create better WEPP user interfaces, and D. C. Flanagan assumed responsibility for model interface development. He recruited Windows programmers and supervised development of a graphical Windows interface (Flanagan et al., 1998). Initial interface work was completed in 1999 and resulted in a user-friendly software program still widely used today. NSERL staff involved in interface development included J. R. Frankenberger, H. Fu, S. J. Livingston, C. R. Meyer, R. C. Vining and G. A. Weesies. D. C. Flanagan (fig. 1), Agricultural Engineer, West Lafayette, Indiana, was appointed WEPP Project Leader in April 1999.

The WEPP Windows interface graphically depicts a side view of a hillslope profile (fig. 4) or a plan view of a small watershed. The default set of projects contains agricultural, rangeland, and forest management inputs for a wide range of conditions. Soil input information can be obtained for thousands of soils in the NRCS Soils-5 and NASIS databases. Information from over 2600 climate stations can be used with the CLIGEN (Nicks et al., 1995) weather generator to produce a time series of synthetic climate inputs for erosion simulations throughout the U.S. Complex slope shapes with multiple soils, cropping, and management conditions can be simulated.

Model outputs are numerous and can be viewed either graphically or in text format. The basic output information on average annual rainfall, runoff, soil loss, and sediment yield is shown in a table at the top right of the screen (fig. 4). Spatial soil loss can be displayed graphically, in a pop-up window, and is also shown in color (to distinguish soil detachment and sediment deposition) in the center slope profile layer (fig. 4). Results of return period analyses can be computed and displayed, indicating the likelihood of runoff or sediment yield to exceed a certain level at the location of interest. 


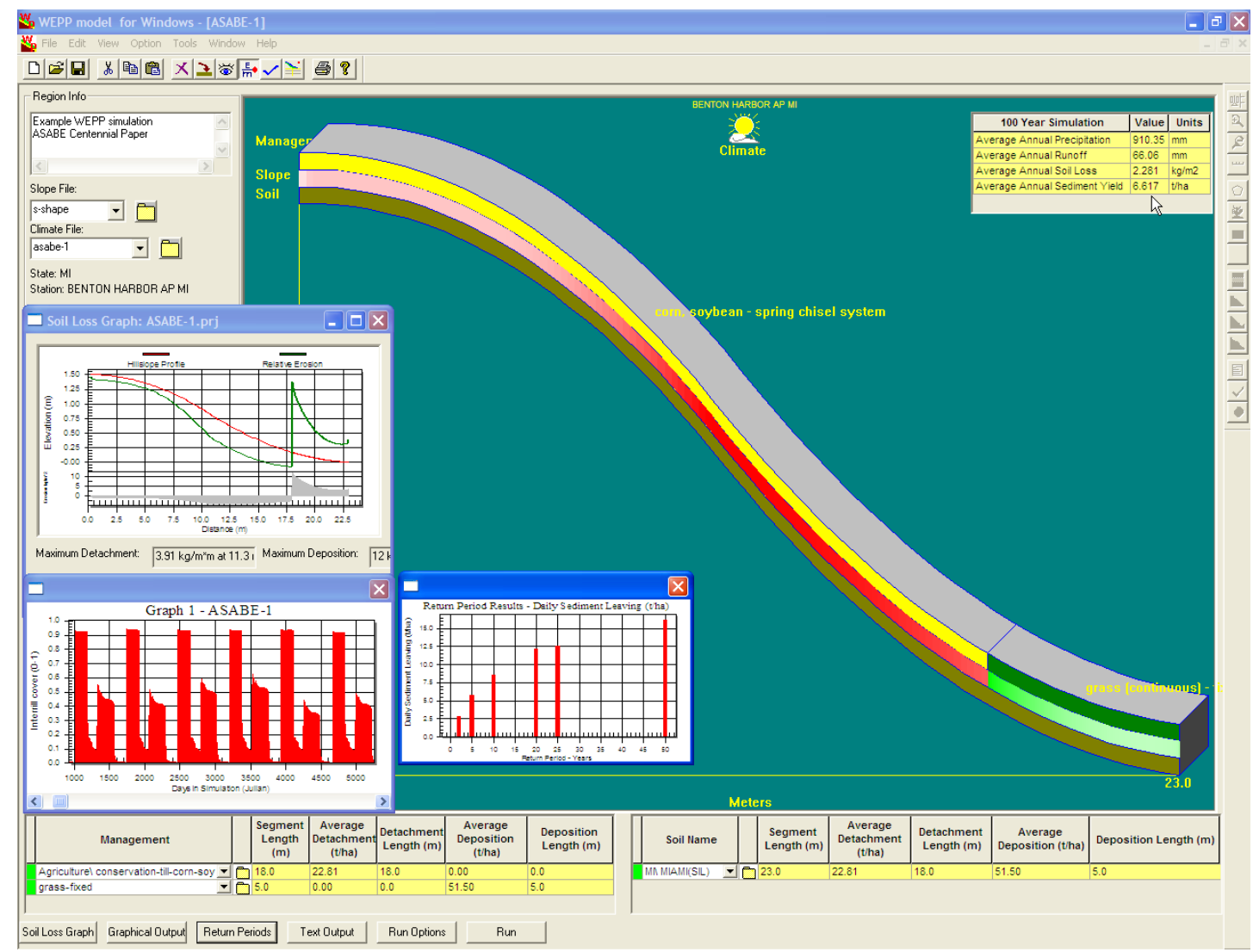

Figure 4. WEPP Windows interface main screen, showing results of an erosion model simulation for a hillslope profile with a cropped area and a grass strip. Optional graphical output windows are shown on the left.

Watershed simulations can also be conducted with the Windows interface. However, while simple watersheds containing a few hillslopes and channels are easy to configure, it becomes increasingly complex and difficult to configure larger areas. As a result, additional work was initiated at the NSERL in 1996 to link the WEPP model with Geographic Information Systems (GIS) and utilize digital elevation data to automatically delineate watersheds, channels, hillslopes, and representative hillslope profiles (Cochrane and Flanagan, 1999). An ESRI ArcView extension known as GeoWEPP (Renschler et al., 2002; Renschler, 2003) was released in 2001. A web-based WEPP GIS system (Flanagan et al., 2004) that allows users to locate and simulate any location in the U.S. via their web browser connected to a server at the NSERL was recently provided (fig. 5). Both this web-based product and GeoWEPP provide spatial graphical display outputs of predicted erosion risk areas in a watershed. Currently, BLM, FS, and other domestic and foreign users are utilizing WEPP technology. From 2001 to 2006, there were over 5700 downloads of the WEPP Windows software from the on-line NSERL site (J. Frankenberger, personal communication). The WEPP software can be accessed at: http://topsoil.nserl.purdue.edu/ nserlweb/weppmain/.

Additional interfaces have been created for use with the WEPP model. The USDA Forest Service Rocky Mountain Research Station (RMRS) has developed a suite of web-based WEPP interfaces. This software was tailored for the design of forest roads, estimating soil loss from roads and timber harvest areas, predicting the potential effects of fires on soil erosion, and for use in fire fuel management (http://forest.moscowfsl.wsu.edu/fswepp/; Elliot, 2004). Conservationists in Brazil have developed the Erosion Database Interface (EDI) to link the USLE and WEPP with geospatial watershed information. The EDI has been employed to estimate the impacts of sugarcane production on runoff and soil loss (Sparovek et al., 2001; Ranieri et al., 2002; de Jong van Lier et al., 2005). Recently, Iowa State University faculty completed a project to estimate near real-time daily runoff and soil loss from each township in Iowa (Cruse et al., 2006), utilizing WEPP and NEXRAD radar precipitation data with results delivered via a web site (http://wepp.mesonet.agron.iastate.edu/). Work also continues at the State University of New York at Buffalo on improvement of GeoWEPP using the more recently released ESRI ArcGIS system (http://www.geog.buffalo.edu/ rensch/ geowepp/).

In addition to interface development, a number of enhancements to the WEPP model science code have also occurred since 1995. Improvements have been made to the CLIGEN weather generator (Meyer et al., 2007), the watershed channel and impoundment components, the daily water balance and evapotranspiration estimates, and subsurface lateral flow predictions along low-permeability layers (Wu et al., 2002; Dun et al., 2006; Pieri et al., 2007; Dun et al., 2007). Vegetation growth algorithms for forest and rangelands have also recently been improved. Many of these model enhancements have resulted from cooperative projects between the NSERL, FS-RMRS (Moscow, Idaho), Washington State University (Pullman, Wash.), and the ARS 


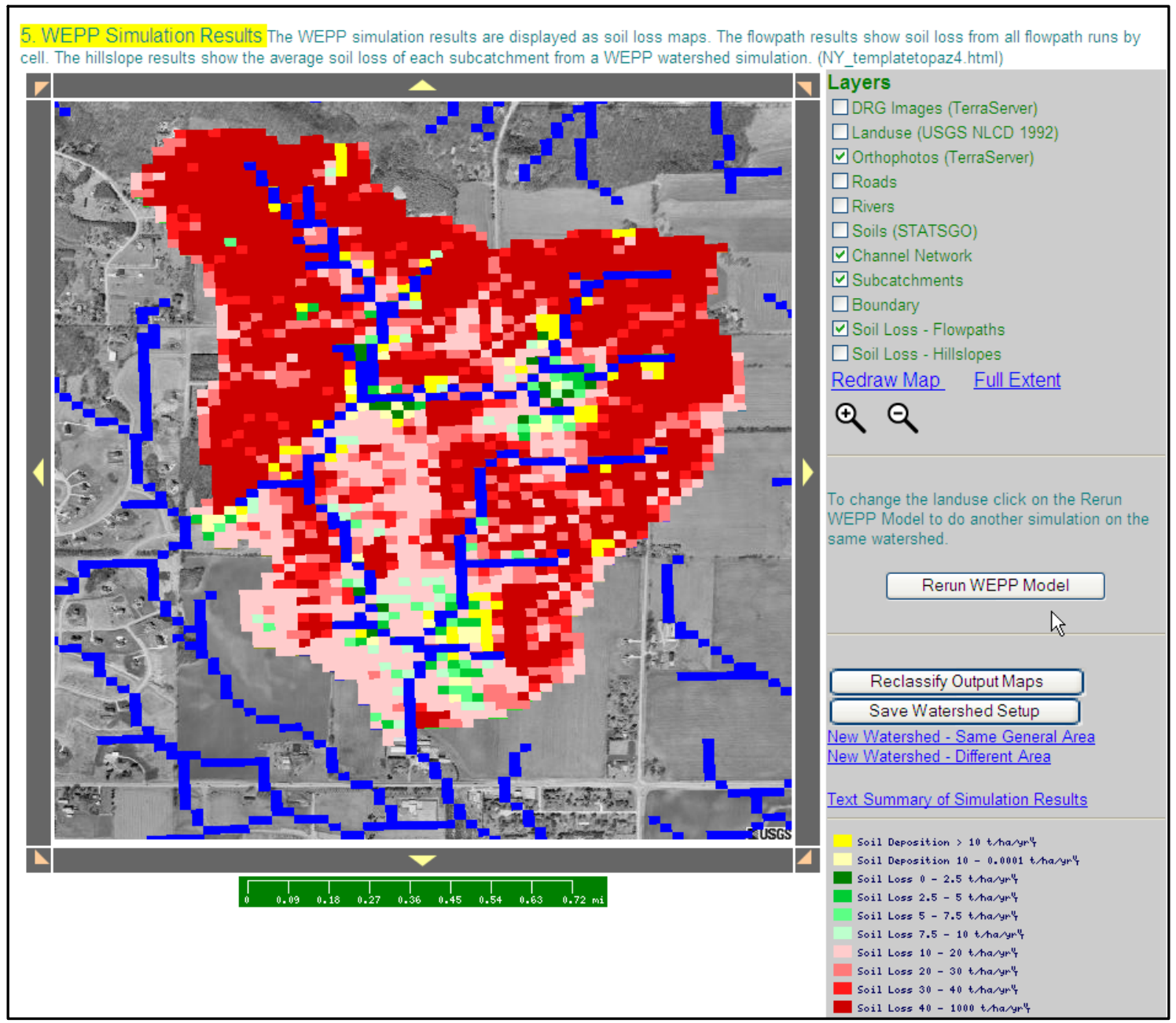

Figure 5. WEPP web-based GIS interface displaying spatial soil loss estimates for a watershed near Madison, Wisconsin (http://milford.nserl.purdue. edu/wepp/gis2.php).

Land Management and Water Conservation Research Unit (Pullman, Wash.). Currently, other items in the WEPP model being examined for possible improvement include the hillslope erosion code, channel temporal erodibility parameterization, and winter period hydrology and erosion (Greer et al., 2006).

Thorough evaluation and testing of the WEPP model has been critical for its acceptance. A multitude of scientific articles on the WEPP model continue to be published (e.g., Ascough et al., 1997; Flanagan and Nearing, 2000; Laflen et al., 2004; Pieri et al., 2007). Many results of formal validation efforts have been reported (Zhang et al., 1996; Liu et al., 1997; Tiwari et al., 2000). In the Tiwari et al. (2000) study, 1600 plot-years of natural runoff plot data from the USLE database was used for verification and validation of uncalibrated WEPP model predictions of soil loss, and WEPP model results were compared to those calculated with both the USLE and RUSLE (Revised Universal Soil Loss Equation). Nash and Sutcliffe (1970) model efficiency for average annual soil loss predictions by WEPP at the 20 sites tested was 0.71 , which was comparable to RUSLE (0.72) and USLE $(0.80)$ values, indicating that overall the model could be used to predict long-term average annual values at those sites without any calibration (as compared to USLE and RUSLE empirical equations, whose parameters were derived in part from the natural runoff plot dataset). Thus, WEPP can be used to estimate long-term average annual soil loss using default parameters. Additionally, unlike USLE, WEPP provides detailed output identifying the location and rates of maximum soil loss and deposition along a slope profile (or within a small watershed), allowing soil conservation planners to target practices to critical areas.

\section{New Modeling Efforts}

WEPP and WEPS science and computer code are currently being used in a new modeling effort to create a combined process-based wind and water erosion model. NRCS has requested that ARS combine these two separate technologies into a single prediction system. The new system will provide a consistent and comprehensive field-office tool that utilizes a common database, single interface, and a single set of routines for hydrology, plant growth, tillage soil disturbance, and residue management and decomposition. To achieve this objective, the hillslope erosion component from WEPP has recently been extracted as an independent computer program (Flanagan et al., 2005).

The WEPP hillslope erosion computer code has also been inserted as a module into the Object Modeling System (OMS). The OMS is a software modeling development 
platform created by the ARS Agricultural Systems Research Unit in Fort Collins, Colorado, that allows model components to be easily built from legacy code in the Fortran, C, and Java programming languages (David et al., 2002). These modules can then be linked to form new models (Ascough et al., 2005). Modules for surface hydrology, water balance, water erosion, and wind detachment, and a prototype model that can simulate either wind or water detachment for multiple storm events have been developed from 2005 to the present. Project plans are to complete a combined wind and water prediction system by 2011 .

\section{WEPP MODEL IMPACT AND LEGACY}

Both the USDA Forest Service and the USDI Bureau of Land Management routinely utilize WEPP on a daily basis to assess soil erosion and determine remediation strategies on the extensive public forests and rangelands that they manage. Many other public and private agencies and individuals within the U.S. are also applying the model. Application of WEPP in over 16 foreign countries can be found in the literature, and in Canada the model has been used extensively by Alberta Agriculture and Food to guide soil conservation research efforts.

In an important application of WEPP to an EPA Superfund site at the former Rocky Flats Nuclear Weapons Plant location in Colorado, the model was used to help identify detachment, transport, and deposition locations of soils contaminated with radioactive wastes, and assist with plans for site cleanup (Clark et al., 2006). This work helped to save an estimated $\$ 30$ billion in taxpayer money in clean-up costs, reduced estimated clean-up time by 60 years, and removed an annual liability of $\$ 600$ million from the Department of Energy's budget (Clark et al., 2006).

WEPP's final legacy has yet to be determined. The project was the first successful attempt to replace an empirically based soil erosion prediction technology (USLE) with a comprehensive fundamentally process-based approach. Of major importance was that this effort took the concept of the separation of interrill and rill erosion processes and put it into a user-friendly continuous simulation model technology. In addition, the field and laboratory experiments necessary to provide parameterization equations so that the model could be widely applied were carefully planned, conducted, and reported. Extensive cooperation and teamwork by a dedicated group of engineers and scientists across the country ensured that WEPP was developed in a timely manner, and that a wide range of conditions would be considered in the model simulations.

\section{SUMMARY}

USDA-ARS employees and their cooperators initiated the WEPP project in 1985 to develop physically based erosion prediction technology for use in soil and water conservation and environmental planning and assessment. Detailed project objectives and guidelines were outlined in a user requirements document. A group of individuals representing several agencies, disciplines, and international locations assisted with project activities. A well-coordinated team effort among project leaders, researchers, and agencies was needed to meet project timelines. Meetings were held periodically throughout the U.S. to coordinate and direct project activities, and extensive field and laboratory experimental research programs were conducted on cropland, rangeland, and disturbed forest areas to obtain information required for model development, parameterization, and testing.

A hillslope computer model and associated documentation were delivered to user agencies in August 1989, and an updated, revised version for both hillslope and watershed simulations was released in August 1995. Because it is physically based, the WEPP model has been successfully used in the evaluation of important natural resources issues throughout the U.S. and in several other countries. Of major importance is that this soil erosion prediction technology successfully implemented the concept of separate rill and interrill detachment processes in an end-user computer simulation program. The technology includes the parameterization equations (based on the extensive experimental component of the project) needed to apply the uncalibrated model.

WEPP model development continued after 1995 on a substantially reduced scale to meet additional user needs and utilize newly released computer software. Recent model enhancements include a graphical Windows interface and integration of WEPP with GIS software. Improvements have also been made to the watershed channel and impoundment components, the CLIGEN weather generator, the daily water balance and evapotranspiration routines, and the prediction of subsurface lateral flow along low-permeability soil layers. Development of a combined wind and water erosion prediction system utilizing WEPP technology and including easily accessible common databases and interfaces is currently underway.

\section{REFERENCES}

Ascough, J. C., II, C. Baffaut, M. A. Nearing, and B. Y. Liu. 1997. The WEPP watershed model: I. Hydrology and erosion. Trans. ASAE 40(4): 921-933.

Ascough, J. C., II, D. C. Flanagan, O. David, and L. R. Ahuja. 2005. Assessing the potential of the object modeling system (OMS) for erosion prediction modeling. ASABE Paper No. 052011. St. Joseph, Mich.: ASABE.

Clark, D. L., D. R. Janecky, and L. J. Lane. 2006. Science-based cleanup of Rocky Flats. Physics Today 59(9): 34-40.

Cochrane, T. A., and D. C. Flanagan. 1999. Assessing water erosion in small watersheds using WEPP with GIS and digital elevation models. J. Soil Water Cons. 54(4): 678-685.

Cruse, R. M., D. C. Flanagan, J. R. Frankenberger, B. K. Gelder, D. Herzmann, D. James, W. Krajewski, M. Kraszewski, J. M. Laflen, and D. Todey. 2006. Daily estimates of rainfall, water runoff, and soil erosion in Iowa. J. Soil Water Cons. 61(4): 191-199.

David, O., S. L. Markstrom, K. W. Rojas, L. R. Ahuja, and I. W. Schneider. 2002. The Object Modeling System. In Agricultural System Models in Field Research and Technology Transfer, 317-330. L. R. Ahuja, L. Ma, and T. A. Howell, eds. Boca Raton, Fla.: Lewis Publishers.

de Jong van Lier, Q., G. Sparovek, D. C. Flanagan, E. M. Bloem, and E. Schnug. 2005. Runoff mapping using WEPP erosion model and GIS tools. Computers and Geosci. 31(2005): 1270-1276.

Dun, S., J. Q. Wu, W. J. Elliot, and P. R. Robichaud. 2006. Adapting the Water Erosion Prediction Project (WEPP) model to forest conditions. ASABE Paper No. 062150. St. Joseph, Mich.: ASABE. 
Dun, S., J. Q. Wu, W. J. Elliot, P. R. Robichaud, D. C. Flanagan, J. R. Frankenberger, R. E. Brown, and A. C. Xu. 2007. Adapting the Water Erosion Prediction Project (WEPP) model for forest applications. J. Hydrol. (submitted).

Elliot, W. J. 2004. WEPP Internet interfaces for forest erosion prediction. J. American Water Res. Assoc. 40(2): 299-309.

Elliot, W. J., A. M. Liebenow, J. M. Laflen, and K. D. Kohl. 1989. A compendium of soil erodibility data from WEPP cropland soil field erodibility experiments 1987 and 1988. NSERL Report No. 3. West Lafayette, Ind.: USDA-ARS National Soil Erosion Research Laboratory.

Flanagan, D. C. ed. 1995. WEPP95 CD-ROM. Distributed at the Soil and Water Conservation Society WEPP/WEPS Symposium. Des Moines, Iowa.

Flanagan, D. C., and S. J. Livingston, eds. 1995. Water Erosion Prediction Project (WEPP) Version 95.7: User summary. NSERL Report No. 11. West Lafayette, Ind.: USDA-ARS National Soil Erosion Research Laboratory.

Flanagan, D. C., and M. A. Nearing, eds. 1995. USDA Water Erosion Prediction Project hillslope and watershed model documentation. NSERL Report No. 10. West Lafayette, Ind.: USDA-ARS National Soil Erosion Research Laboratory.

Flanagan, D. C., and M. A. Nearing. 2000. Sediment particle sorting on hillslope profiles in the WEPP model. Trans. ASAE 43(3): 573-583.

Flanagan, D. C., D. A. Whittemore, S. J. Livingston, J. C. Ascough, and M. R. Savabi. 1994. Interface for the Water Erosion Prediction Project model. ASAE Paper No. 942105. St. Joseph, Mich.: ASAE.

Flanagan, D. C., B. A. Engel, J. M. Laflen, and S. C. Nelson. 1995. A multimedia CD-ROM for delivery of WEPP technology. ASAE Paper No. 952388. St. Joseph, Mich.: ASAE.

Flanagan, D. C., H. Fu, J. R. Frankenberger, S. J. Livingston, and C. R. Meyer. 1998. A Windows interface for the WEPP erosion model. ASAE Paper No. 982135. St. Joseph, Mich.: ASAE.

Flanagan, D. C., J. C. Ascough II, M. A. Nearing, and J. M. Laflen. 2001. Chapter 7: The Water Erosion Prediction Project (WEPP) model. In Landscape Erosion and Evolution Modeling, 145-199. R. S. Harmon and W. W. Doe III, eds. New York, N. Y.: Kluwer Academic / Plenum Publishers.

Flanagan, D. C., J. R. Frankenberger, and B. A. Engel. 2004. Web-based GIS application of the WEPP model. ASAE Paper No. 042024. St. Joseph, Mich.: ASAE.

Flanagan, D. C., J. C. Ascough II, W. F. Geter, and O. David. 2005. Development of a hillslope erosion module for the object modeling system. ASAE Paper No. 052012. St. Joseph, Mich.: ASAE.

Foster, G. R, and L. J. Lane. 1987. User requirements: USDA Water Erosion Prediction Project (WEPP). NSERL Report No. 1. West Lafayette, Ind.: USDA-ARS National Soil Erosion Research Laboratory.

Gilley, J. E., and D. C. Flanagan. 2007. Early investment in soil conservation experiment stations continues to provide dividends. Trans. ASABE 50(5): 1595-1601.

Gilley, J. E., E. R. Kottwitz, and J. R. Simanton. 1990. Hydraulic characteristics of rills. Trans. ASAE 33(6): 1900-1906.

Greer, R. C., J. Q. Wu, P. Singh, and D. K. McCool. 2006. WEPP simulation of observed winter runoff and erosion in the U.S. Pacific Northwest. Vadose Zone J. 5(1): 261-272.

Hagen, L. J., L. E. Wagner, and J. Tatarko. 1996. Wind erosion prediction system: WEPS technical documentation. Manhattan, Kansas: USDA-ARS-Wind Erosion Research Unit. Available at: www.weru.ksu.edu/weps/docs/weps_tech.pdf. Accessed March 2007.
Laflen, J. M., W. J. Elliot, J. R. Simanton, S. Holzhey, and K. D. Kohl. 1991. WEPP soil erodibility experiments for rangeland and cropland soils. J. Soil Water Cons. 46(1): 39-44.

Laflen, J. M., D. C. Flanagan, and B. A. Engel. 2004. Soil erosion and sediment yield prediction accuracy using WEPP. $J$. American Water Res. Assoc. 40(2): 289-297.

Lane, L. J., and M. A. Nearing, eds. 1989. USDA Water Erosion Prediction Project: Hillslope profile model documentation. NSERL Report No. 2. West Lafayette, Ind.: USDA-ARS National Soil Erosion Research Laboratory.

Liu, B. Y., M. A. Nearing, C. Baffaut, and J. C. Ascough II. 1997. The WEPP watershed model: III. Comparisons to measured data from small watersheds. Trans. ASAE 40(4): 945-952.

Meyer, C. R., C. S. Renschler, and R. C. Vining. 2007. Implementing quality control on a random number stream to improve a stochastic weather generator. Hydrol. Proc. (in press).

Nash, J. E., and J. V. Sutcliffe. 1970. River flow forecasting through conceptual models: Part 1. A discussion of principles. J. Hydrol. 10(3): 282-290.

Nearing, M. A., G. R. Foster, L. J. Lane, and S. C. Finkner. 1989. A process-based soil erosion model for USDA Water Erosion Prediction Project technology. Trans. ASAE 32(5): 1587-1593.

Nicks, A. D., L. J. Lane, and G. A. Gander. 1995. Chapter 2: Weather generator. In USDA Water Erosion Prediction Project hillslope and watershed model documentation. D. C. Flanagan and M. A. Nearing, eds. NSERL Report No. 10. West Lafayette, Ind.: USDA-ARS National Soil Erosion Research Laboratory.

Pieri, L., M. Bittelli, J. Q. Wu, S. Dun, D. C. Flanagan, P. R. Pisa, F. Ventura, and F. Salvatorelli. 2007. Using the Water Erosion Prediction Project (WEPP) model to simulate field-observed runoff and erosion in the Apennines mountain range, Italy. $J$. Hydrol. 336: 84-97.

Ranieri, S. B. L., Q. de Jong van Lier, G. Sparovek, and D. C. Flanagan. 2002. Erosion database interface (EDI): A computer program for georeferenced application of erosion prediction models. Computers and Geosci. 28(5): 661-668.

Renschler, C. S. 2003. Designing geo-spatial interfaces to scale process models: The GeoWEPP approach. Hydrol. Proc. 17(5): 1005-1017.

Renschler, C. S., D. C. Flanagan, B. A. Engel, and J. R. Frankenberger. 2002. GeoWEPP: The geospatial interface to the Water Erosion Prediction Project. ASAE Paper No. 022171. St. Joseph, Mich.: ASAE.

Simanton, J. R., M. A. Weltz, and H. D. Larsen. 1991. Rangeland experiments to parameterize the Water Erosion Prediction Project model: Vegetation canopy cover effects. J. Range Mgmt. 44(3): 276-282.

Sparovek, G., Q. de Jong van Lier, S. B. L. Ranieri, I. C. DeMaria, and D. C. Flanagan. 2001. Application of a database interface (EDI) for erosion prediction in Brazil. Revista Brasileira de Agrocomputacao (Brazilian J. Agrocomputation) 1(1): 5-12.

Tiwari, A. K., L. M. Risse, and M. A. Nearing. 2000. Evaluation of WEPP and its comparison with USLE and RUSLE. Trans. ASAE 43(5): 1129-1135.

Wischmeier, W. H., and D. D. Smith. 1978. Predicting Rainfall Erosion Losses: A Guide to Conservation Planning. Agriculture Handbook No. 537. Washington, D.C.: USDA.

Wu, J. Q., A. C. Xu, and W. J. Elliot. 2002. Adapting WEPP (Water Erosion Prediction Project) for forest watershed erosion modeling. In Proc. 12th ISCO Conf., IV: 349-355. International Soil Conservation Organization.

Zhang, X. C., M. A. Nearing, L. M. Risse, and K. C. McGregor. 1996. Evaluation of runoff and soil loss predictions using natural runoff plot data. Trans. ASAE 39(3): 855-863. 